Article

\title{
Wealth, Well-Being, and the Danger of Having Too Much
}

\author{
Dustin Crummett \\ Department of Philosophy, University of Notre Dame, 100 Malloy Hall, Notre Dame, IN 46556, USA; \\ Dustin.R.Crummett.1@nd.edu \\ Academic Editors: Kate Ward and Kenneth Himes \\ Received: 5 February 2017; Accepted: 26 April 2017; Published: 8 May 2017
}

\begin{abstract}
It is impossible for an agent who is classically economically rational to have so much wealth that it is harmful for them, since such an agent would simply give away their excess wealth. Actual agents, vulnerable to akrasia and lacking full information, are not economically rational, but economists, ethicists and political philosophers have nonetheless mostly ignored the possibility that having too much might be harmful in some ways. I survey the major philosophical theories of well-being and draw on ethics and the social sciences to point out several ways in which, on the most plausible of these theories, having too much, relative to other members of one's society, might be harmful to oneself (for instance, by making it harder for one to have appropriate relationships with others, or by making it more likely than one will develop undesirable character traits). I argue that because egalitarian policies prevent these harms and provide the advantaged with other benefits (such as access to public goods which help rich and poor alike), egalitarian policies are not as harmful to the rich as is commonly supposed, and may even be helpful to them on balance. I close by discussing the practical implications of this.
\end{abstract}

Keywords: political philosophy; ethics; well-being; economic inequality; psychology

\section{Introduction}

In 2013, around the time the idea which later became this paper initially occurred to me, the twenty-five highest earning hedge fund managers in the United States together brought in about 24.3 billion dollars in personal income (Vardi 2014). Average median income for an American wage earner that year was estimated to be $\$ 28,031.02$ (Social Security Administration 2013), which means that the twenty-five hedge fund managers collectively made as much as about 867,000 median wage earners (that's 34,376 workers apiece). Because much of their income derives from "management fees", which they receive regardless of how well their funds actually perform, managers can rake in tremendous amounts of money even when it's questionable whether they contribute anything to the economy, much less as much as thirty-five thousand average workers (Vardi 2014; Creswell 2011). An especially striking example of this is Steve Cohen, who made 2.3 billion dollars in 2013-the same year his firm paid 1.8 billion dollars in fines for insider trading, and despite the fact that his investments significantly underperformed the Dow Jones, NASDAQ, and S\&P 500 indices (Vardi 2014; Rooney 2013). In fairness, though Cohen did worse than the indices, he did, apparently, "beat most other hedge fund managers" (Vardi 2014). The situation with regard to material inequality is hardly better if we look at wealth, rather than income; between them, the four-hundred richest Americans are worth about as much the bottom one-hundred ninety-four million (Frank 2015).

There are a lot of good reasons to be worried about this state of affairs and others like it. We might worry on behalf of the forty-seven million Americans who live in poverty (DeNavas-Walt and Proctor 2015). We might worry on behalf of American workers, who must deal with not only the hardship but also 
the insult of having had their wages stagnate or decline for decades while the rich grow ever richer (Greenstone and Looney 2012; Matthews 2012) We might worry on behalf of those in poverty in the developing world whose lives might have been drastically improved with the money that went to the managers. We might worry about our society, whose democratic character might be threatened by extreme material inequality (see (Stiglitz 2012)). We might even worry on general grounds of economic efficiency, which is not likely to be promoted by paying people billions of dollars for doing a bad job. However, it might not occur to us to worry that all this is bad for the hedge fund managers themselves. I want to argue here that perhaps it should.

Say that people who make, say, tens of millions of dollars or more per year, or who have many tens of millions of dollars or more in assets, and who mostly keep their money or spend it on goods or services for themselves, all while other people, and particularly other members of their own society, have so much less, are living lives of vast wealth (or, for short, are vastly wealthy). I intend this as a semi-technical definition. It's possible (though extremely unusual) to live a life of vast wealth without ever actually being wealthy, provided you spend your money fast enough. It's also possible to be extremely wealthy without living a life of vast wealth; the definition is meant to exclude people who make such sums and then, say, give most to the Gates Foundation, as well as people who use the bulk of their money in ways which, though not exactly altruistic, are nonetheless unusually productive from society's point of view (e.g., starting a business which produces something of great importance). I take no stand here about these groups of people here. I will also not attempt to figure out how well those who are wealthy, but don't reach the level of vastly wealthy, are doing. (Some of my arguments will apply to the merely very wealthy, but not all will). ${ }^{1}$

As for the effect of living lives of vast wealth, I consider two questions. The first question takes for granted that you live in a society basically like the present United States and asks what the effect on your well-being of living a life of vast wealth is likely to be, as compared to the effect of living, say, a comfortable middle-class life, or perhaps a merely very wealthy life. I argue that it's plausible that it will tend to be pretty bad for you, or at least not nearly as good as one might think. (I think this is true especially, but not exclusively, for rent-seekers who acquire their wealth in a way that's more or less unconnected from whether they're producing anything of social value). The second asks whether those who live lives of vast wealth would be better off in a more egalitarian society which discouraged or prevented them from living such lives. I argue that, because such a society would prevent them from experiencing the harms of that kind of life while also providing them with improved access to certain public goods, it's plausible that they would be better off. Both of these are questions in ethics: they have to do with what's good for the people in question. The consequences for social and political philosophy are not immediately obvious. For instance, we might think that the purpose of government is to ensure that people have the ability to live their lives as they see fit, regardless of whether those lives are good or bad for them and, in fact, without making any judgments about what's good or bad for people at all, and that attempting to prevent the wealthy from harming themselves by acquiring too much would be objectionably paternalistic. In the final section, I consider the social and political implications of our answers to the first two questions. Treating the fact that living a life of vast wealth is bad for one as a reason to implement egalitarian distributive policies may be objectionably paternalistic, though I argue that this is far from obvious. But even if it is objectionably paternalistic, I think the position I defend, if taken to heart, could play a useful role in developing and promulgating an attractive egalitarian ethos.

1 Roughly speaking, the reason for focusing specifically on the vastly wealthy is that there clearly are some benefits of being very wealthy, and some reasons why it might be bad for one to be vastly wealthy, which don't apply to merely being very wealthy. My thought is that there are greatly decreasing marginal benefits involved in going from very to vastly wealthy, as well as additional harms, so that the case for vast wealth being overall harmful is easier to make than the one for being merely very wealthy. This leaves open the question of whether being very wealthy is overall good or bad for someone. 
My fellow ethicists and political philosophers in the analytic tradition have mostly dismissed the possibility that, outside of special circumstances, having too much wealth might be seriously bad for you. ${ }^{2}$ I think (Rawls 1999, p. 123)) is representative when, defending the claim that the parties in the original position would want to maximize their share of material resources, he writes:

I have assumed throughout that the persons in the original position are rational. But I have also assumed that they do not know their conception of the good. This means that while they know that they have some rational plan of life, they do not know the details of this plan...How, then, can they decide which conceptions of justice are most to their advantage?...I postulate that they...assume that they normally prefer more primary social goods rather than less. Of course, it may turn out, once the veil of ignorance is removed, that some of them for religious or other reasons may not, in fact, want more of these goods. But from the standpoint of the original position, it is rational for the parties to suppose that they do want a larger share, since in any case they are not compelled to accept more if they do not wish to.

When Rawls talks about "advantage" here, he is speaking, not directly about one's well-being, but about one's ability to pursue one's rational plan of life. However, for Rawls, these are intimately related; see Part III of $A$ Theory of Justice, which winds up endorsing a kind of desire-satisfaction view. (Ultimately, the things I say about the effects on our well-being of vast wealth according to desire satisfaction views should apply to Rawls' own view of our well-being, as well as to the question of whether vast wealth is helpful or harmful in our pursuit of our rational plan of life). Besides this, two things are notable about this passage. One is that Rawls apparently thinks that extreme wealth could frustrate our preferences only if we have unusual preferences, such as wanting to be a religious ascetic. The other is that he thinks that, even if having more wealth would frustrate our preferences, this wouldn't be very concerning, since we could just refuse it.

The first point will be a major target throughout the rest of this paper. As far as the second point is concerned, Rawls is relying on a standard conception of economic rationality according to which agents always have all the information relevant to satisfying their preferences and always pursue their preferences in the most efficient manner:

The concept of rationality invoked here...is the standard one familiar in social theory. Thus in the usual way, a rational person is thought to have a coherent set of preferences between the options open to him. He ranks these options according to how well they further his purposes; he follows the plan which will satisfy more of his desires rather than less, and which has the greater chance of being successfully executed (Rawls 1999, pp. 123-24).

Assuming that well-being consists of satisfying one's preferences (see Section 2), agents who were like this usually couldn't be harmed by excess wealth. As long as no one forced the agent to take it, they could just decline any excess wealth, and if they wound up with a harmful level of wealth (say, by inheriting it as a child, or because their plans changed), then as long as there were no barriers to getting rid of it, they could just give it away. While the parties in the original position are stipulated to be economically rational, however, they are supposed to be the representatives of real human agents, who are not. Real humans do not always know which actions will best fulfill their preferences, and I will argue in Section 3 that, contrary to what many of us suppose, it's plausible that extreme wealth often tends to frustrate many of our most important preferences. Likewise, humans, being susceptible to akrasia - weakness of will—often act in ways which they realize will needlessly frustrate their preferences (see (Stroud 2014)). Furthermore, as I discuss in the next section, fulfilling your

2 Of course, there has been a great deal of discussion about economic inequality more broadly (see, e.g., Lamont and Favor (2013) for an overview). What philosophers have dismissed is the specific claim that too much money might be bad for you. 
preferences may not always be good for you anyway. Of course, Rawls (as I explain in the final section) realized that actual human agents were not literally economically rational in the sense above; presumably, what he thought was that this conception was close enough to actual human behavior, while also being manageably simple, to justify the assumption for purposes of the original position. Part of what I hope to show here, however, is that, when it comes to the topic at hand, this may very well be false, and at any rate can't just be assumed.

Against the consensus, a few philosophers have considered the possibility that extreme wealth might be harmful. (Wolff (2015, pp. 212-13)) notes that a historically prominent egalitarian tradition does just that:

...there is an egalitarian tradition of questioning the value of material resources, and especially the culture of consumption. A good life is one of friendship, creation and appreciation of art and literature, development of creativity, and mutual support... This view, associated with William Morris and John Ruskin, is that material resources are a snare and a distraction...

And Harry Frankfurt, in his recent book On Inequality, writes that:

In addition to the incidence of poverty, another part of our current economic disorder is that while many of our people have too little, quite a number of others have too much. The very rich have, indisputably, a great deal more than they need in order to live active, productive, and comfortable lives. In extracting from the economic wealth of the nation much more than they require in order to live well, those who are excessively affluent are guilty of a kind of economic gluttony...

Apart from harmful psychological and moral effects upon the lives of the gluttons themselves, economic gluttony presents a ridiculous and disgusting spectacle. Taken together with the adjacent spectacle of a sizeable class of people who endure significant economic deprivation, and who are as a consequence more or less impotent, the general impression given by our economic arrangements is both ugly and morally offensive (Frankfurt 2015, pp. 3-5).

But neither Wolff nor Frankfurt does much to develop these thoughts; (Frankfurt 2015, 5, fn. 1) explicitly says that while the "moral and psychological problems arising from the fact that some people have too much are eminently worthy of study and analysis", he will (understandably) instead focus on the "more pressing phenomenon of people who have too little". I attempt to develop and defend the view here.

Furthermore, and perhaps surprisingly, neither Wolff nor Frankfurt takes these as reasons to be concerned about economic inequality as such. (Wolff (2015, pp. 212-13)) sympathetically glosses the view he discusses as being that, since material resources are a snare and a distraction, "...those who think that we must equalize resources are missing the point and falling into a form of fetishism." Wolff instead endorses social egalitarianism, which posits that people are owed a society in which they relate to others as equals, but that whatever material differences are compatible with this are fine. (Some social egalitarians think that very few material differences are compatible with this, so that social equality requires a substantial degree of economic inequality; see, e.g., (Scheffler 2015). But Wolff's comment about "fetishism" suggests that he doesn't think this). Meanwhile, Frankfurt thinks the problem is not inequality, exactly, but that some have so much while others don't have enough. The rest of his book argues that distributive justice has been achieved once everyone has enough, where "to say that someone has enough money means-more or less-that he is content, or that it is reasonable for him to be content, with having no more money than he actually has" (Frankfurt 2015, p. 47); past that point, concern because some have more than others "tends to distract [those concerned] from recognizing their most authentic ambitions, which are those that derive from the character of their own lives, and not those that are imposed on them by the conditions in which others happen to live" 
(Frankfurt 2015, p. 89). My arguments will imply that those living lives of vast wealth are harmed both because they do so while others do not have enough and because they do so while having vastly more than the others members of their society, regardless of whether those others have enough. Exactly what this means for egalitarians will be discussed in Section 5 .

In the next section, I survey the elements involved in the major philosophical accounts of well-being: hedonism, desire theory, objective list theory, and hybrid theories. In Section 3, I consider the impact of living a life of vast wealth on well-being, arguing that is probably bad (or least not as good as you might think) according to the most plausible versions of any of these theories. In Section 4, I consider the impact of egalitarian distributive policies upon the wealthy, arguing that those living lives of vast wealth would probably tend to be better off in societies which made it harder to do so. In Section 5, I discuss some of the implications for social and political philosophy of the earlier sections. Parts of my argument will be somewhat tentative. At times, I will appeal to empirical judgments which seem plausible to me but which it is hard to be sure about, and at times I will appeal to normative judgments which I don't have adequate space to defend here. Nonetheless, I hope to establish that there is a strong case in favor of my conclusions.

\section{Accounts of Well-Being}

Philosophers have discussed four major families of theories of well-being — of what, fundamentally, makes your life go well or poorly for you (see (Parfit 1984), Appendix I for a historically important overview, and (Crisp 2013) for a more recent one). Hedonists (e.g., (Crisp 2006)) think that well-being consists of pleasant phenomenal states (such as the pleasing warmth I feel when I rub the bellies of my cats, Apollo and Artemis) and that ill-being consists of nasty ones (such as the sharp pain I feel when Apollo decides he's had enough and scratches me). The more and better the nice experiences you have, the better your life is for you, and vice versa. Desire theorists (e.g., (Rawls 1999, chp. 7)) think that well-being consists in the satisfaction of one's desires, or of some subset of one's desires, while ill-being consists in their frustration. Generally, the more and stronger the relevant desires which you satisfy, and the fewer and weaker your relevant frustrated desires are, the better your life is for you. ${ }^{3}$ Both hedonists and desire theorists are subjectivists, insofar as they think that whether something is good or bad fundamentally depends wholly, in one way or another, on my mental states.

By contrast, objective list theorists (e.g., (Griffin 1986)) think that, while pleasure or desire satisfaction may be components of our well-being, other states of affairs can also be intrinsically good or bad for us regardless of the attitudes or hedonic responses we have towards them. ${ }^{4}$ There are many candidates for inclusion on the list, and objective list theorists need not claim to have identified all of the list's elements; Derek Parfit (Parfit 1984, p. 499) suggests as paradigmatic objective goods "moral goodness, rational activity, the development of one's abilities, having children and being a good parent, knowledge, and the awareness of true beauty" and as paradigmatic objective list evils "being betrayed, manipulated, slandered, deceived, being deprived of liberty or dignity, and enjoying either sadistic pleasure, or aesthetic pleasure in what is in fact ugly."

Finally, many philosophers (e.g., (Kagan 2009)) are attracted to the thought that there must be some sort of objective element to our well-being, but doubt that anything could be good for us while we remain totally cold to it (for a statement of this as a criticism of the objective list theory, see (Railton 1986, p. 9)). These hybrid theorists think, that for something to be good for us, it must be true both that we have some subjective response to something (such as enjoying it (Kagan 2009) or wanting it, e.g., (Lauinger 2013)) and that the thing in question has the right kind of objective value.

3 There are variants of the desire theory which treat some attitude other than desires as important; Heathwood (2014, p. 202) suggests as candidates "favoring something, wanting it, caring about it, valuing it, believing it valuable, liking it, trying to get it, having it as a goal, being fond of it, being for it, having an interest in it, and the like." Nothing about which attitude we pick should make a big difference to my argument, so, for ease, I'll just continue speaking of "desires."

4 For a similar approach, see James O'Sullivan's account of capabilities theory in his essay in the current volume. 
(As Heathwood (2014, p. 207) puts the point, the hybrid theory suggests that "well-being consists in receiving things that (1) the subject has some pro-attitude toward... and that (2) have some value, or special status, independent of these attitudes. One's life goes better not simply when one gets what one wants or likes, but when one is wanting or liking, and getting, the right things." $)^{5}$ This partition of theories is not logically exhaustive, and the boundaries between them are not always precise, ${ }^{6}$ but they give us a good sense of the major lines philosophers have pursued when thinking about well-being.

These theories can all agree that well-being consists in having one of, or some combination of, three things: nice hedonic states, desire satisfaction, and objective goods. Likewise, they agree that ill-being consists in having one of, or some combination of, three things: nasty hedonic states, desire frustration, and objective bads. My method in the next section, then, will be to consider what impact living a life of vast wealth might have on each of these putative components of well-being; we can then use our judgments about the impact on these putative components to determine what the impact will be according to whatever overall theory we endorse. I will argue that, by the metric of any of these components, living a life of vast wealth will probably tend to be bad (or at least only minimally good) for us, and accordingly that living such a life will not be a good bet, regardless of which theory we hold. I hope that what I say will be have fairly broad appeal, but at times I will appeal to points which seem plausible according to my own sympathies (which lie in the direction of an objective list or hybrid theory) but are controversial. Accordingly, I will first say a bit about my views on how these different components relate to well-being.

I think it's clear that hedonic states play some role in our well-being; that agony is intrinsically bad for us, for instance, seems about as clear to me as anything. On the other hand, I'm somewhat skeptical that desires are intrinsically important for well-being. The mere fact that I desire something does not seem to me to be the right sort of thing to explain why that thing's good for me; rather, I think I desire things because (among other reasons) I think that, for reasons other than the fact that I desire them, they would be good for me and therefore worth desiring. (This is a statement of what's often called the "direction of fit objection" - intuitively, I desire things because they're good for me, not the other way around). While it's often true that getting something I desire would be good for me, and would not be good for me if I did not desire that thing, I think the most plausible cases of that form can be explained by other considerations (for instance, the fact that getting what I want usually brings me enjoyment; see (Parfit and Scheffler 2011, pp. 65-70) for a series of arguments which can be adapted to support my view). ${ }^{7}$ But my view is in the minority, so that it will be important to consider which is the most plausible way to flesh out a view on which desires are intrinsically important to our well-being. This turns out to be a complicated question.

We could hold that any time I have a desire and it is satisfied, this is intrinsically good for me. But this isn't plausible. At the very least, we should say that only things which I desire in themselves, rather than instrumentally, can contribute to my well-being. If I want a hat only because I think it will make me look cool, and I care about looking cool in and of itself, then what matters in itself is only looking cool. (If, for some reason, I can't get the hat, but I look cool for some other reason, the fact that I didn't get the hat wouldn't matter). I also think it is plausible that the only desires which intrinsically matter for me are those which I have and would still have in some suitably idealized condition (e.g., one where I was fully informed about the relevant matters, instrumentally rational, and mentally healthy. Exactly how to spell out the idealized condition in question is controversial, and I won't attempt to sort it out here). For instance, if I want to marry someone who is cheating on me but I wouldn't want

5 Hybrid theorists have a number of options about what constitutes harm; see Shelly Kagan's (as far as I know, unpublished) paper "What is Ill-being when Well-being is Enjoying the Good?"

6 E.g., Heathwood (2006) argues, I think implausibly, that the most credible versions of hedonism and the desire theory are actually the same theory.

7 The section is about desire theories of reasons, rather than well-being, but most of the suggestions have relevant analogues. 
to if I knew the truth, then it seems plausible to think that fulfilling my goal of marrying that person won't be intrinsically good for me.

There is also a further question about the scope of the desires whose satisfaction or frustration might directly affect contribute to my well-being. Parfit 1984, p. 494) suggests that if I briefly meet a stranger, and altruistically form a desire that the stranger's disease be cured, it's implausible that the stranger's later being cured, unbeknownst to me, is good for me. The idea here would be that, for a desire to make a difference to my well-being, it must be about my life in some important way. However, people sympathetic to this view will often agree that some desires which are largely about things other than my own life can affect my well-being. Parfit himself (Parfit 1984, p. 495) suggests that the desire to be a successful parent is about your life in the relevant way, even though whether the desire is satisfied will depend largely on how the lives of other people (namely, your children) go. Heathwood (2014, p. 215) suggests that the desire theorist should expand the scope even further, allowing your desire that your favorite sports team win to intrinsically affect your well-being, even though, assuming you don't play for the team, this is about your life only in a very tenuous sense. I won't take a stance on which, exactly, is the most plausible way to draw the line is question. But I do think that, if desires intrinsically affect our well-being, desires such as those that I help, and not harm, my loved ones and my community will do so.

Finally, there are the objective goods. As my remarks have already indicated, I am convinced that there must at least be some objective element to well-being. Nozick (1974, pp. 42-45) asks us to imagine the experience machine, a virtual reality device capable of stimulating our brain so as to delude us into thinking that we are accomplishing great deeds, forming blissful relationships, and so on, all while we are really closed up in a machine somewhere. I do not think a life spent entirely in the experience machine would be terrible for you. (If I wanted to wreak terrible vengeance on my foe, putting him in the experience machine to experience intense but delusional ecstasy would not really be my first choice). But I (and Nozick) think it is clear that an otherwise similar life in which you really did those great things would be better for you; accordingly, merely having nice subjective experiences is not enough for an ideally fulfilled life. Desire theorists can avoid saying that someone in the experience machine has an ideal life, since many of their desires are actually unfulfilled. (What I desire, presumably, is to do great deeds, form blissful relationships, and so on, not just to feel like I am doing those things). But Rawls has us imagine a "grass-counter", whose only intrinsic desire is to "count blades of grass in various geometrically shaped areas such as park squares and well-trimmed lawns" (Rawls 1999, p. 379) and who then successfully does that a lot. We can say that he holds onto the desires after becoming fully informed, instrumentally rational, free of pathologies, and so on. Rawls is willing to bite the bullet and say that, if he gets to spend lots of time counting grass, the grass-counter's life is good for him. But I doubt many of us are tempted to envy him; his life seems to me at most as good as one in the experience machine, depending on how much he enjoys what he's doing. So merely getting what you desire, even if that is also accompanied by pleasure, is not enough for an ideal life, either. I think examples like these can undermine any purely subjective theory of well-being, showing that it makes a difference whether we are really engaged with things of objective value.

This, alone, doesn't tell us whether we should favor an objective list or hybrid theory of well-being. I am fairly sympathetic to thinking that certain things can harm us, whether or not we care about them. If you don't care about the fact that your child hates you, this may well make you worse, rather than better, off. I'm more sympathetic to the thought that even things of objective value can't be good for you if you're totally cold to them, though I'm uncertain. On the other hand, I do think that pleasure can be good for us, even if it's taken in something without objective value. For instance, I doubt there is anything objectively valuable about making toy airplanes dogfight, but if I enjoy doing that (which, in fact, I do,) doing that seems good for me. However, while I think pleasure can be good for me even if taken in something without objective value, I also think that the contribution pleasure ultimately makes to my well-being can be affected by the objective value of what the pleasure is taken in. So, for 
instance, if my pleasure was taken in something of objective value rather than in making the toy planes dogfight, maybe that would be better for me. Meanwhile, malicious pleasure taken in the suffering of some innocent stranger certainly seems less good for me than harmless pleasure taken in playing with the planes, if the former sort of pleasure is even intrinsically good for me at all. ${ }^{8}$ For similar reasons, I think we should say that the intrinsic contribution to our well-being made by satisfying desires likewise varies with the objective value of the thing desired, if desire satisfaction makes an intrinsic contribution to our well-being.

I will not attempt to come up with any comprehensive list of objective goods; I have no such list. Instead, I will simply note what I think are some plausible candidates, as they become relevant. Of course, that there are objective elements to our well-being does not imply that there is any one, unique way of living which is best for people. Suppose, for instance, that appreciation of beauty isn't really my thing. There are plenty of other objectively valuable things with which to engage, and the fact that any plausible theory will put some at least some weight on what I desire or enjoy means that pursuing those will probably be better for me. Nonetheless, if something prevents me from fully engaging with a wide range of important objective goods, then it seems plausible that this will reduce my well-being, especially if they are things which people tend to enjoy or care a lot about.

\section{Living a Life of Vast Wealth}

\subsection{Hedonic States}

There are some saints who rejoice in physical hardship. For the rest of us, pleasant hedonic states tend to have material preconditions. For a pleasant life, one usually needs at least some food, shelter, clean water, and so on. Once one's physical needs are met, wealth can allow one to provide for one's loved ones, gain peace of mind through financial security, obtain better medical care and engage in pleasurable leisure activities and stimulating projects. But there will clearly be a point at which this levels off. Barring extenuating circumstances, a member of the upper middle class in a modern Western nation can easily enjoy a material standard of living that, in most respects, vastly exceeds that available to literally anyone in the world throughout the vast majority of human history. There is clearly some sort of limit to how much pleasure one can get from material goods, at least given a certain level of technological development: one's food can't be but so tasty, one's environment can't be but so temperate, one's pillows can't be but so comfortable, and one's gizmos can't fit but so many whirligigs. Consider Buffett (2010) statement regarding his decision to give away the vast majority of his fortune:

More than $99 \%$ of my wealth will go to philanthropy during my lifetime or at death. Measured by dollars, this commitment is large. In a comparative sense, though, many individuals give more to others every day.

Millions of people who regularly contribute to churches, schools, and other organizations thereby relinquish the use of funds that would otherwise benefit their own families. The dollars these people drop into a collection plate or give to United Way mean forgone movies, dinners out, or other personal pleasures. In contrast, my family and I will give up nothing we need or want by fulfilling this $99 \%$ pledge...

This pledge will leave my lifestyle untouched and that of my children as well. They have already received significant sums for their personal use and will receive more in the future.

8 There are two ways to think about what's happening in these cases. One is to say that the value for me of the state of affairs my experiencing pleasure changes depending on what the pleasure is taken in. The other is to say that the value of the state of affairs my experiencing pleasure is constant regardless of what the pleasure is taken in, but that the value for me of the state of affairs my experiencing pleasure in some innocent stranger's suffering is less the sum of the values for me of the states of affairs my experiencing pleasure and some innocent stranger suffering. (For a relevant discussion, see (Dancy 2004, chp. 10)). This is a technical point without practical implications for us here. I think the latter view is correct, but will sometimes speak as if the former view is true, just because doing so is easier. 
They live comfortable and productive lives. And I will continue to live in a manner that gives me everything that I could possibly want in life.

Empirical evidence suggests that the average American's overall evaluation of how well their life is going continues to improve into higher income levels (Kahneman and Deaton 2010). (This is what we would expect if they believe that having more money increases well-being, whether or not it does). However, their day-to-day evaluation of their emotional states-of "the frequency and intensity of experiences of joy, fascination, anxiety, sadness, anger, and affection that make one's life pleasant or unpleasant" (Kahneman and Deaton 2010, p. 16489)—stops increasing somewhere around the decidedly middle-class amount of $\$ 75,000$ a year (Kahneman and Deaton 2010, p. 16489). Even up to this point, increased income seems to increase happiness primarily by making it easier to cope with life's misfortunes, rather than by, say, allowing one to buy nicer things. (That is to say, as one approaches $\$ 75,000$, it's not so much that one's baseline level of happiness increases as it is that that the decreases in happiness caused by things like divorces or illnesses are less pronounced (Kahneman and Deaton 2010, p. 16489)).

These data do not focus on the vastly wealthy, however. One could speculate that perhaps emotional well-being begins increasing again after some threshold is reached. Maybe certain, extremely expensive things are just far more fun than any cheaper items. But I see no particular reason to think that's true. We could speculate, I think with at least as much intuitive plausibility, that vast wealth tends to add stress to one's life, and so to make one worse off by the standard of hedonic well-being. After all, one has more to keep track of and more to potentially lose. This is suggested by Buffett's remark that:

Some material things make my life more enjoyable; many, however, would not. I like having an expensive private plane, but owning a half-dozen homes would be a burden. Too often, a vast collection of possessions ends up possessing its owner. The asset I most value, aside from health, is interesting, diverse, and long-standing friends.

Additionally, in some cases, there are fairly concrete reasons for thinking that, by the metric of hedonic well-being, one will be made worse off by vast wealth. For instance, I'll discuss in the next section the fact that extreme wealth may tend to have negative effects on one's personal relationships. A vast body of research (e.g., (Feeney and Collins 2015)) suggests that healthy relationships are an important component of emotional well-being. So, I think that, if anything, the evidence makes it more likely that there tends to be a negative impact on one's emotional well-being as income continues to increase.

Furthermore, if there are hedonic benefits that come with living a life of vast wealth, it's plausible to think that these will primarily come as a result of comparative, rather than absolute, advantages. That is to say, the pleasure will come as a result of favorably comparing the amount of money you have, or what you consume, to the amount of money you had or what you were consuming in the past, or to what the other people in your social circle have or consume. (see (Frank 2011)). If, as I suggested earlier, the contribution which pleasure makes to our well-being depends on what it's taken in, it's not clear to me that pleasure taken just in having material advantages over others will be of much benefit to us. Furthermore, implementing egalitarian distributive policies will likely leave many of these comparative advantages in place; unless the policies are very radical, they will allow some to be wealthier than others, and will allow people to become wealthier throughout the course of their lives. If the vastly wealthy benefit from these comparative advantages, the fact that many of them will be left in place, even as the absolute amount of wealth available to the vastly wealthy decreases, will help blunt whatever negative impact egalitarian distributive policies might have on them.

As far as I'm aware, then, there is no direct research on the usual hedonic impact of living a life of vast wealth, as opposed to living a comfortable upper-middle class life, or a merely very wealthy life. However, I think there no particular reason to expect it to be positive, and some reason to expect it be negative. By the metric of hedonic states, living a life of vast wealth at least doesn't seem to be a particularly smart bet. Further, to the extent that there are hedonic advantages from living a life of 
vast wealth, it seems plausible to think that many of them will not be severely negatively impacted by egalitarian distributive policies.

\subsection{Desire Satisfaction and Objective Goods}

People who believe in objective goods tend to think that they are the things we would desire for ourselves if we were fully informed, rational, mentally healthy, and so on. Meanwhile, desire theorists tend to think the things we would usually desire if fully informed, etc. are those on the objective list. This isn't a coincidence; part of the reason for adding the conditions about full information and the rest to the desire theory are to allow it to accommodate the common sense intuitions about what sorts of things are usually good for us which objectivists rely on in developing their lists of goods. (There is probably not any plausible way for the desire theorist to rule out, in principle, people like the grass-counter, whose desires are fixed on seemingly pointless and arbitrary things despite being fully informed, etc. But by adding idealization conditions, and by also claiming that most of us wouldn't want stuff like that if we met those conditions, desire theorists can say that their theory gives the intuitively correct answer as to what would be good for us in the vast majority of normal cases). Because of this tendency to agree, it will be convenient to discuss desire satisfaction and objective goods alongside one another. I will begin by discussing some possible ways in which living a life of vast wealth might be good for us by these measures, and will then discuss some ways in which it might be bad. Of course, there is no way to consider every possible benefit or harm which might result; instead, I'll simply note what occur to me as the major ones.

\subsubsection{Possible Benefits}

Some people pretty clearly desire vast wealth for its own sake. They want, for instance, to grow their already tremendous fortunes, not because there is any conceivable use for their money, but just because they desire more money. I'm not aware of any philosopher who has claimed that living a life of vast of wealth is in itself objectively valuable; on the contrary, objectivists have often asserted that money is only instrumentally valuable (see, e.g., I-II.Q2.A2 of the Summa Theologica). As for desire satisfaction, there are three things to be said. One is that if we think that the value of satisfying a desire varies with whether the thing desired is objectively valuable, then satisfying this desire does not seem likely to be very valuable. The second is that I doubt many people really would maintain this desire if fully informed, rational, and mentally healthy. This would mean realizing and internalizing the fact that this kind of life is (as I discussed above) not likely to improve one's emotional well-being and has the drawbacks I discuss below, and nonetheless holding onto the desire. This does not strike me as a typical reaction. The third point to make is that how strongly we intrinsically desire various levels of wealth is shaped by how much others in our society have, and how much we have right now. It may, then, again be the case that egalitarian distributive policies would not harm the vastly wealthy on this score, since their desires would adjust to be for levels of wealth which were achievable under the egalitarian scheme. (At least, this might be true for those raised under the egalitarian scheme; it may not be true for a vastly wealthy person as an egalitarian scheme is implemented). Similar remarks apply if someone desires, not an absolute amount of money, but just to have as much or more money than others.

Someone might also desire financial security for themselves and their loved ones, and someone might likewise think that providing our loved ones with such security can itself be an intrinsic good for us, even if we don't wind up needing it. This strikes me as fairly reasonable. However, while it's hard to say precisely how much financial security is enough, it seems safe to say that the vastly wealthy have achieved this level many, many times over. Someone with just nineteen million dollars has enough to give themselves a \$75,000 annual stipend from 2017 until the USS Enterprise returns from the successful completion of the five-year voyage of exploration portrayed in Star Trek: The Original 
Series..$^{9}$ Someone who, having that much—or even any significant fraction of that much-continued to pursue the accumulation of wealth for reasons of financial security would be carrying a reasonable precaution to a pathological degree.

Better candidates for benefits might involve things like aesthetic or cultural engagement. Vastly wealthy people can easily travel without the hassle most of us face, since they can do things like buying or renting private jets; they can feel at home in foreign countries, since they can literally own homes there; they can buy the originals of important works of art; and so on. ${ }^{10} \mathrm{I}$ can understand these things being candidates for objective goods, and I can understand finding them appealing even if you think they probably won't add much more pleasure to your life. In addition, there may be other good things which are part of such a lifestyle and which I haven't imagined. (Admittedly, never having lived that way, it might be hard for me to imagine all the perks). But these potential benefits must be balanced against the potential harms which I discuss next.

There are also some goods which are difficult for upper-middle class people to afford, but easily available to both very wealthy and vastly wealthy people. An anonymous referee suggests that I should count "having access to the most recent (and hence very expensive) medical care if one needs it" and "university education for all one's children's at the world's best universities, without putting your children in debt" as being among the benefits of vast wealth. Clearly, these sound appealing. However, they are also usually easily affordable for people who are "merely" multi-millionaires, without being vastly wealthy (in my semi-technical sense). If things like this outweigh whatever harms may be associated with being merely very wealthy, then this would be an argument for being very wealthy, but not for being vastly wealthy: one could have these benefits while avoiding those harms, discussed in Section 3.2.2, which apply to the very but not vastly wealthy. It would be fine for purposes of my argument if there is some much lower level of wealth at which vastly wealthy people would, ceteris paribus, tend to be much better off (or at least not much worse off,) though there is a further question about which level would be optimal.

\subsubsection{Possible Harms}

I think there are a number of ways in which living a life of vast wealth might be harmful by the metrics of desire satisfaction or objective goods. I will consider five here. Some of these only involve an increased statistical chance of some bad outcome obtaining, while others are more or less inherent to living a life of vast wealth in a way that makes them very difficult to avoid, at least in circumstances like ours. The first is that, in living a life of vast wealth, one is complicit in the perpetrating of inequalities which (it is plausible to think) have disastrous effects upon one's society. There is a strong case to be made that severe inequality in income and wealth hinders economic growth, weakens democratic institutions, erodes social trust, undermines the rule of law, and leads to a wide variety of poor social outcomes, such as worsened health and higher crimes rates (Stiglitz 2012; Wilkinson and Pickett 2010; Schlozman in the present volume). Even a very wealthy person who doesn't engage in the most flagrant behaviors driving this process-by, say, using their money to gain political influence-still contributes to this process to some degree by claiming wealth and income which might otherwise be more evenly divided. Likewise, they still benefit, in a way most of us find unsavory, from a state of affairs which is detrimental to society as a whole. The complicity in harm is especially pronounced when the money in question is gained through rent-seeking, since, in those cases, there is not any countervailing social benefit produced.

Most of us do not want to be complicit in bringing harm on our society or our communities. It's not just that we desire, on our community's behalf, that it not come to harm, though hopefully we do

9 Nineteen million dollars divided by seventy-five thousand dollars is $253.333 \ldots$, meaning it could run from 2017 until a few months into 2271. The Enterprise's mission lasts from 2265-2270.

10 I'm grateful to Paul Weithman for pressing me on this point. 
desire that; we also desire, for ourselves, that we not be the agents of that harm. (Suppose you learned that something bad had befallen your country; suppose you learned, further, that you were partly responsible for that bad thing. Wouldn't you feel even worse after learning the new information?) In addition, being complicit in this kind of harm seems like a plausible candidate for an objective bad. Accordingly, such complicity is likely to be bad for us by the metrics of desire satisfaction and objective considerations.

Second, extreme wealth seems to have a corrosive effect on one's character. Having a bad character is a plausible candidate for an objective bad, and most of us desire to have a good, and not a bad, character. Again, it isn't just that, from a disinterested moral perspective, we want everyone to be virtuous, and therefore want ourselves to be virtuous as well (though this may also be true). It's that we want, for ourselves, to be a certain kind of person. (Imagine the difference in your reaction from realizing that you possess a serious character flaw about which you had deceived yourself versus your reaction at merely learning that some stranger who you'd never met possessed that flaw). Thus, by either of the two metrics considered here, it seems plausible that being vicious will be bad for us.

Kate Ward has argued from a theological perspective that wealth grants the condition of hyperagency which can interfere with the pursuit of virtues like humility and justice (Ward 2016). There is also a substantial body of empirical work on more mundane vices which are associated with being rich. Despite having more to spare than poorer people and (due to the possibility of tax deductions) experiencing less of a financial marginal cost with each dollar they give, richer people tend to give a substantially lower percentage of their income to charity than poorer people; furthermore, when the rich do give, they are more likely to give to relatively morally trivial causes that primarily benefit themselves and other rich people, such as art museums, and less likely to give to organizations that actually help those in need (Independent Sector 2001; Stern 2013). These results are reflected in experimental situations, where lower class individuals are more generous to anonymous strangers (Piff et al. 2010). (It is true that, in recent years, hundreds of billionaires have pledged to give away half of their fortunes as part of an effort spearheaded by Bill Gates and Warren Buffett. But the substantial majority of signatories appear to enjoy the positive publicity without actually fulfilling the requirements of the pledge; see (Coffey 2015)).

Additionally, the wealthy score higher on personality tests intended to measure narcissism and a sense of entitlement (Piff 2013) and, at least in some experimental situations, appear to be less trusting (Piff et al. 2010). They exhibit significantly lower levels of compassion and are less empathetic to the point of being worse at reading other people's facial expressions (Kraus et al. 2012). Richer people are more likely to cut off other cars and pedestrians while driving, more likely to cheat in games with small monetary prizes (despite, obviously, needing the money less), and are more likely to withhold vital information from job candidates in mock interviews (Piff et al. 2013). Priming experimental subjects with feelings of chaos leads makes lower-class participants, relative to upper-class participants, more likely to want to participate in community building activities, while it makes upper-class participants relatively more likely to say that they would sacrifice communal ties for an increased salary and more likely to express agreement with statements like "I feel that money is the only thing I can really count on" and "I believe that time not spent making money is time wasted" (Piff et al. 2012). Additionally, there is good reason to think that these flaws are partly caused by, rather than merely correlated with, class, since merely increasing feelings of being wealthy in experimental subjects (by asking them to think about people who are poorer than they are) brings out many of the same anti-social behaviors as are found among those who are actually wealthy. For instance, subjects who are so primed tend to eat more candy from a supply they're told is intended for children participating in a later experiment (Piff et al. 2013) (that is, merely feeling wealthy literally makes you take candy from children!).

Furthermore, these vices and others may be exacerbated among those who live lives of vast wealth from the start. Willis (2013), part of the family that started the Georgia-Pacific corporation 
and now a psychotherapist who works with wealthy families, writes that she wiled away her youth because her wealthy upbringing left her lazy and without a drive to engage in meaningful work:

The biggest curse of intergenerational wealth for me and many other people is the illusion that you don't have to do much with your life... My wandering 20s were an example of too much too soon. My parents wanted me to enjoy the freedom of youth. They meant for my financial ease to be a gift. Unfortunately, it didn't occur to me to do anything with my life...

Recently, a client said to me, "When you're raised by rich people you're not taught to do anything." You're not taught to do practical things, because everything is done for you. It's a challenge to hone the skills you need to function outside of that setting.

Many people who aren't wealthy think it would be great to not have to learn to do anything, or just to learn what one chooses. Perhaps they don't recognize the value of feeling confident and building a purposeful, meaningful life. The only way to get there is to tough out mistakes and failures. Though inheritors are given many things, no one is given a meaningful life. For that we all have to work.

Willis likewise writes that ingratitude is another "curse" of family wealth:

Ingratitude. We all know what this looks like. It is the attitude of entitlement and arrogance. Ingratitude is insidious, based on fear and anger. It leads to low self-esteem, insecurity and the self-doubt that comes from never having become good at anything.

When I was in my 20s, ingratitude ruled my life. Due to my lack of experience working with others, I thought everything had to be exactly the way I wanted it. Planning for my first wedding, at age 29, I threw a fit that there were no gardenias available in January. I was inconsolable. The florist provided some kind of white flowers, as close as they could come to the gardenias I coveted, and I was furious.

Of course, we could find many other stories to the same effect. The point here is not to romanticize poverty, which puts strains of its own on one's character. The point is instead that after one no longer faces the constant insecurity, or social stigma, or physical threats, or other factors which produce such strain, accumulating substantially more opens one up to the vices discussed above. From the perspective of well-being, this may be dangerous.

Third, living a life of vast wealth often has deleterious effects both on one's personal relationships and on one's relationship with the broader communities which one is a part of. Most of us value these relationships, and such relationships are plausible candidates for being objectively important, so, again, whether these relationships are healthy or dysfunctional may be important to our well-being. It's easy to see what sorts of what bad impacts developing the negative character traits just described might have on one's personal relationships. For instance, (Kraus et al. 2012, p. 559) argue that even among intimates such as romantic partners, the wealthy are significantly more likely to form what they call "exchange relationships" - in which "individuals seek to trade relationship benefits with partners (e.g., emotional support, responding to needs) for equal value, and they keep track of costs and benefits within their relationships" - and less likely to simply respond to the needs of their loved ones without trying to get something out of it.

Cohen (2009, pp. 5-6) contrasted the norms governing a camping trip-in which people willingly cooperate without trying to maximize their own advantage - with the exchange norms which govern market transactions:

You could imagine a camping trip where everybody asserts her rights over the pieces of equipment, and the talents, that she brings, and where bargaining proceeds with respect to who is going to pay what to whom to be allowed, for example, to use a knife to peel the potatoes, and how much he is going to charge others for those now peeled potatoes that he bought in an unpeeled condition from another camper, and so on. You could base 
a camping trip on the principles of market exchange and the strictly private ownership of shared facilities.

Now, most people would hate that.

Cohen goes on to argue that camping trip norms, rather than market norms, ought to govern the economy as a whole. That is supposed to be the controversial part of the argument; he plausibly supposes that no one would really want to run a camping trip as an exchange relationship. Yet the wealthy, whatever they want, are apparently more likely to form exchange relationships, not only on camping trips, but also everywhere else.

In concrete terms, these problems sometimes show up in the family lives of the extremely wealthy. Willis (2013) suggests that, within familial contexts, extreme wealth tends to lead to "too much financial focus:"

This focus can be so big that families neglect human, intellectual and social capital in the family. As a result, there's no balance. Instead, the emphasis is on the dollars, the assets, the strategies and the money managers. Family meetings only cover financial concerns. Some of my wealthy clients have spent years looking for a way to bring up family communication, relationships, and effective parenting.

Indeed, there exists an entire industry of books by counselors and wealth advisors (e.g., (Willis 2012); (Collier 2012); (Lombardo 2012)) aimed wholly or largely at helping the extremely wealthy deal with the potential impact of wealth on their families. (One of these books (Lombardo 2012) has the unsettling subtitle "Why Rich Kids Hate Their Parents!") And many of the wealthy themselves seem to recognize the potential problem; one study focusing primarily on families with one hundred million dollars or more in assets, almost half of inheritors were "highly concerned" that their inheritance would negatively impact their personal relationships (Frank 2012a). (I am not aware of any data suggesting that this makes them noticeably more likely to turn down or give away their fortunes, however).

Many of us also value the relations we stand in with members of communities-churches, schools, cities, states, countries, religions, and so on-which stretch far beyond the group of people we directly interact with. (This is often especially evident after tragedies, where members of the affected community express a sense of kinship and solidarity with one another, even if the community is far too large for all of the people in it to have met). These sorts of relations can also be strained by living a life of vast wealth. In some cases, this is because, as mentioned above, living such a life involves active complicity in harming the community. But it can also be because living such a life cuts one off from certain shared experiences and struggles. As Cohen (2009, pp. 35-36) notes:

We cannot enjoy full community, you and I, if you make and keep, say, ten times as much money as I do, because my life will then labor under challenges that you will never face, challenges that you could help me cope with, but do not, because you keep your money. To illustrate. I am rich, and I live an easy life, whereas you are poor... You have to ride the crowded bus every day, whereas I pass by you in my comfortable car. One day, however, I must take the bus, because my wife needs the car. I can reasonably complain about that to a fellow car driver, but not to you. I can't say to you: “It's awful that I have to take the bus today." There is a lack of community between us of just the sort that naturally obtains between me and the fellow car-driver. And it will show itself in many other ways, for we enjoy widely different powers to care for ourselves, to protect and care for our offspring, to avoid danger, and so on. ${ }^{11}$

We might quibble over the degree to which a difference in income of ten times will generate this lack of community. But if I make tens of thousands of times as much as my compatriots, it will be hard for me

11 For more (in a very different context) on how shared adversity can deepen relationships, see (Ekstrom 2013), esp. p. 271. 
to even know about, much less share in, the struggles of ordinary people. In an important way, I am alienated. $^{12}$

Fourth, many religious traditions suggests that one's spiritual life is likely to be harmed by vast wealth. Christianity is my religion, and the only one I am really qualified to discuss, and this is certainly the view of the New Testament. Wealth is viewed as competing with God for one's affections, and as an impediment to being fully dedicated to carrying out God's will (e.g., Matthew 6:19-24). The New Testament goes as far as to promise apocalyptic judgment against the wealthy, sometimes in lurid terms (e.g., James 5:1-5). But even setting aside questions of punishment, nearly any religion views spiritual fulfillment as the best thing possible for a human being, and anything which prevents such fulfillment as to be avoided, even at great cost. If this is right, and if living a life of vast wealth is in tension with such fulfillment, then such a life will be a tragedy.

Fifth, it is possible that those living lives of vast wealth tend thereby to harm their loved ones, and especially their children, by facilitating their loved ones living lives of vast wealth. I've discussed a number of ways in which living such a life may be harmful, and have suggested that some of these harms may be particularly pronounced for those who are born into vast wealth. The vastly wealthy tend to promote their family members living such lives, both by leaving them inheritances and by providing them with plush living conditions, gifts, financial assistance, and so on. They thereby inflict these harms on those they care the most about. The wealthy actually tend to share the worry I discuss here, though it doesn't seem to reliably change their behavior. Survey data suggests that eighty-two percent of millionaires want their children to create their own wealth, (Frank 2013), and only thirty-two percent are convinced that their children are responsible enough to handle inheriting their fortunes (Frank 2012b). They nonetheless often leave their children substantial inheritances (Frank 2013), for understandable reasons. (For one thing, it could pretty awkward not to, though some form of akrasia may also play a part). More than four-fifths of millionaires say that raising their children well is their most important goal (Frank 2013), and doing so (and otherwise doing good, and not harm, to one's loved ones) is a plausible candidate for an objective good. This could, then, raise a serious threat to the well-being of those living lives of vast wealth.

My own judgment is that the possible harms surveyed in this section will tend to outweigh the possible benefits. The possible benefits of living a life of vast wealth seem to me to be things which are nice but inessential. Meanwhile, living such a life may threaten things, such as one's relationships with one's loved ones, community, and God, or one's ability to be a virtuous person, which are among the core constituents of well-being. Accordingly, from the perspective of desire satisfaction or objective goods, I think that living a life of vast wealth will tend to be bad, and perhaps extremely bad. But even if we disagree, it at least seems safe to say that, by these metrics, living such a life will tend not to be as good as one might think.

\section{Egalitarian Societies}

I'll now consider whether those inclined to live lives of vast wealth would do better under a more egalitarian economic scheme which made it prevented them from doing so harder for them to do so, or at least to do so to the same degree. There are several ways in which they might be harmed. First, if some people actually benefit from living lives of vast wealth, their achieving these benefits might be hampered by egalitarian distributive policies. ${ }^{13}$ However, the argument of the last section provides two reasons for thinking we shouldn't be too worried about that. The first is that, if the previous sections are correct, living such a life is usually not good for you. The second is that, as I noted, some of the supposed benefits may result from having more than others, or more than one used to have, or

12 Wealthy people also tend to be literally, physically separated from everyone else; see (Florida and Mellander 2015).

13 For a review of one such policy, the Earned Income Tax Credit, see the essay by Quinn and Cahill in the present volume. 
from meeting some socially conditioned standard of wealth, and these benefits (to the extent that they really are benefits) may be left largely intact by egalitarian policies.

Admittedly, there may well be some short-term subjective harms imposed upon the vastly wealthy by implementing egalitarian societies. They may be made unhappy by the facts of having their taxes raised, or of having less income than they used to have, or of needing to make some lifestyle adjustments; likewise, these things may frustrate some of their desires. ${ }^{14}$ But I suspect that they would adjust, and that these subjective harms would be relatively short-lived. The top marginal tax rate in the United States in 1963 was ninety-one percent (Shiller 2012). Implementing a tax rate anywhere near that today would be unthinkable; even if something like that was somehow made law, the backlash would be tremendous. But I don't see much evidence that wealthy people are all that much happier about paying their taxes now than they were then, or that wealthy Americans are much happier about paying their taxes than are wealthy Europeans who live in countries with much higher tax rates. Given that they will have more than plenty either way, wealthy people seem to adjust to differing economic schemes. (By contrast, the poor do not seem to adapt to poverty (Clark et al. 2013)). ${ }^{15}$

We might also worry that egalitarian policies would prevent or discourage the vastly wealthy from doing things with their money other than keeping it or spending it on themselves, such as giving it to charity or devoting it to socially valuable forms of entrepreneurship. Insofar as these other things can be meaningful forms of engagement with things outside oneself, using money for these might more plausibly be thought to contribute positively to one's well-being. Remember that, at the beginning, I said I would take no stand on people who use most of their money for things like this. However, people living lives of vast wealth often use some of their money for things like this. It might be thought that, the less post-tax income and wealth they have, the greater the marginal cost (in terms of giving up stuff they want, or whatever) they perceive themselves to experience from charitable giving, so that higher tax rates would deter activities like this. If activities like this promote one's well-being, this might harm them. Further, insofar as these things produce more social value than whatever other people would have done with the money, we would lose out on the added social value these activities provide. However, economic policy can also provide forces which push in the other direction. For instance, if people are allowed to deduct charitable donations or entrepreneurial expenses from their taxes, then higher tax rates may encourage people to put their money towards these things, since the marginal economic cost of doing so would be lower (due to the attendant tax deductions being higher (see (Shiller 2012)). Of course, the net result will depend on the specifics of the case and the exact sort of egalitarian policies we have in mind. But the point is just that, even granting the presuppositions of this worry, it may not be as big a problem as it might at first appear.

On the other hand, there are a number of ways in which these people might be better off in a more egalitarian society. If I'm correct in thinking that living lives of vast wealth tends to be harmful, an egalitarian scheme would prevent those harms. But an egalitarian society might also promote public

14 People are substantially more bothered by losing money they already have than by failing to gain additional money, as the literature on "loss aversion" in behavioral economics (e.g., (Kahneman et al. 1991)) has shown.

15 The philosophical literature on "adaptive preferences" shows us that sometimes, the fact that someone will adjust to a hardship does not make things much better. If, say, a member of a marginalized group, believing that they will never gain basic rights, decides, sour-grapes style, that they don't want such rights anyway, or never aspires to having such rights to begin with, this doesn't seem to make the denial of basic rights any less harmful or any more morally justifiable. It might be thought that appealing to the fact that the vastly wealthy will adjust is objectionable in a way analogous to appealing to the fact that some members of marginalized may adjust. But the case for being worried about adaptive preferences is strongest when adapting one's preference involves giving up a desire for a basic constituent of well-being, or to something which forms a core part of one's identity. Being content with merely having plenty of money is hardly like this. So, for instance, Serene Khader (2011, p. 42), appealing to an objectivist understanding of well-being, suggests that adaptive preferences are problematic when they are "(1) preferences inconsistent with basic flourishing that are (2) formed under conditions unconducive to basic flourishing and (3) that we believe people might be persuaded to transform upon normative scrutiny of their preferences and exposure to conditions more conducive to flourishing." But learning to be content while living under the sort of economic scheme possessed by, say, the European social democracies does not meet any of these conditions. (If anything, if the argument of this paper is correct, the opposite is true!) 
goods, or reduce social dysfunction, in ways which benefit everyone, including the very wealthy. The economist Robert H. Frank (2012c) suggests a thought experiment:

Let's say that two societies differ only in their mixes of public and private spending. In one society, lower taxes on the wealthy allow them to drive very fine cars-say, $\$ 180,000$ Bentleys. The streets and highways in this society, however, are riddled with foot-deep potholes. In the other society, the wealthy pay higher taxes that support well-maintained roads, but drive $\$ 120,000$ BMWs...

In which society would the wealthy be happier? Because product-quality improvements cost much more to achieve beyond some point, the absolute quality of a $\$ 180,000$ car may be only slightly higher than one costing $\$ 120,000$. Additionally, because not even the most sophisticated automotive suspensions can neutralize deep potholes, it's little wonder that most people think the BMW drivers would be happier, not to mention safer.

In fact, as noted earlier, concrete data shows that material inequality is associated with a wide range of social ills, from worsened health to higher crime (Wilkinson and Pickett 2010, chp. 4-12), and there is reason to think the relationship is at least partly causal (Wilkinson and Pickett 2010, pp. 190-96). These problems disproportionately affect the poor, but many also harm the rich, sometimes in surprising ways. For instance, increased material inequality seems to reduce health and life expectancy, not only for the poor, but also for the rich (Wilkinson and Pickett 2010, p. 84), perhaps for reasons having to do with status anxiety and reduced social trust (Wilkinson and Pickett 2010, chp. 3). Of course, there is plenty of room for further work here. But in light of these considerations, it seems plausible to me that those living lives of vast wealth would tend to be better off, and perhaps much better off, under a more egalitarian scheme.

\section{Implications}

If the argument of the last two sections is correct, then egalitarian economic policies might benefit, not only those at the bottom, but also many of those at the top. There is a further question about whether the government should treat this as a reason to implement the egalitarian economic policies. It might be claimed that this would be objectionably paternalistic, insofar as it would involve interfering, ostensibly for their own good, with what the vastly wealthy want to do. It might be claimed that the job of government is not to make people better off, but rather to (say) protect citizens' ability to pursue their own conceptions of the good without the government making judgments about whether their conception of the good is correct or whether they are pursuing it in an efficient way. This worry is strengthened by the fact that one of the considerations to which I appealed in explaining how vast wealth might be harmful was religious; if (as we should) we believe in a liberal society, then we believe that promoting religious goods is not a suitable goal for the government, and so believe that any case for paternalistic intervention would need to do without that consideration.

But keep in mind that it may well be that many of the vastly wealthy would largely agree with the value judgments I made above, and that they continue living lives of vast wealth due to empirical ignorance of the consequences, or failure to see the implications of what they know, or weakness of will. Paternalistic intervention in those cases would represent, not the imposition of an alien conception of the good, but rather an attempt to help the people in question better achieve their own aims. If any kind of paternalism is acceptable, it would be this (for what is probably the best defense of paternalism of this sort, see (Conly 2012)), though even that sort is extremely controversial (see some of the essays in (Coons and Weber 2013)). (However, it is worth noting that in our society there is very broad support for many policies which seem to be most naturally interpreted as involving this kind of paternalism, such as seat belt laws). (Rawls 1999, p. 218)) himself thought that the parties in the original position would be open to allowing paternalistic interventions which promote the rational preferences of those interfered with (though, as I mentioned earlier, he is primarily concerned about their rational plans of life, not their well-being as such): 
It is...rational for them to protect themselves against their own irrational inclinations by consenting to a scheme of penalties that may give them a sufficient motive to avoid foolish actions and by accepting certain impositions designed to undo the unfortunate consequences of their imprudent behavior. For these cases the parties adopt principles stipulating when others are authorized to act in their behalf and to override their present wishes if necessary; and this they do recognizing that sometimes their capacity to act rationally for their good may fail, or be lacking altogether. Thus the principles of paternalism are those that the parties would acknowledge in the original position to protect themselves against the weakness and infirmities of their reason and will in society. Others are authorized and sometimes required to act on our behalf and to do what we would do for ourselves if we were rational, this authorization coming into effect only when we cannot look after our own good. Paternalistic decisions are to be guided by the individual's own settled preferences and interests insofar as they are not irrational, or failing a knowledge of these, by the theory of primary goods.

If my arguments about the implications of the desire satisfaction theory of well-being are correct, then the "settled preferences" of the vastly wealthy would in fact be promoted by egalitarian economic policies. Accordingly, if my arguments have succeeded, then the remark from Rawls which I quoted in the introduction is misguided: past a certain point, the parties in the original position should perhaps consider denying themselves more primary goods.

But apart from all this, it may be possible to take the arguments of earlier chapters as providing a non-paternalistic reason to implement egalitarian policies. Here's why: it may be that some vastly wealthy people would prefer, ceteris paribus, to live in a more economically egalitarian society, and that they would prefer this for themselves, not merely for disinterested reasons. Perhaps they feel this way due to some of the considerations mentioned in this paper. (Of course, they could always move to a society with more economic equality, but the fact that they don't doesn't show that they wouldn't, ceteris paribus, prefer to live in such a society, since might require them to give up a lot, such as connections to friends, family, and places they've grown to love). However, no vastly wealthy person can make our society an economically egalitarian one simply by relinquishing their own vast wealth. If they simply relinquished their own wealth, they would not experience the increased public goods mentioned in Section 4. Furthermore, recall that there were a number of times in Section 3 when I suggested that certain advantages of being vastly wealthy depended on how wealthy one was relative to other very wealthy people; any such advantages would be lost if the people in question gave up their vast wealth while others didn't. These factors mean it may turn out that there are vastly wealthy people who would be better off if all the vastly wealthy gave up their vast wealth, and who would prefer that they do so, but who will be rendered worse off if they, so to speak, unilaterally disarm. Enacting egalitarian economic policies to help them would not be paternalistic. ${ }^{16}$ A rough analogy can be drawn with minimum wage laws. Opponents of such laws sometimes portray them as a kind of paternalism, saying that, if workers want to work for less than the minimum wage, they should be allowed to do so. A response is to say that workers will tend to be better off if all workers (perhaps because they are required by law) do not work unless they are paid the minimum wage, but that individual workers will suffer if they hold out for the minimum wage and all other workers do not, since they will simply not get jobs. The minimum wage would then not be a paternalistic policy, but a solution to a kind of coordination problem. It may well still hurt some workers, but the defender

16 An anonymous referee for Religions suggests another interesting way in which this might work. I noted in Section 3.2 .2 that the wealthy often given their children substantial inheritances, against their better judgment. Presumably, part of the reason for this is that social norms put strong pressure on them to do so. It's possible that certain egalitarian policies, like very high estate taxes, might remove this pressure by making it the case that rich people generally can't give their children very large inheritances. The fact that others can't do so would then be a benefit to those who don't want to, but are pressured into doing so. 
of the minimum wage claims that this is an acceptable consequence. In the same way, an egalitarian might defend egalitarian economic policies, not as a kind of paternalism, but in order to help those vastly wealthy who reasonably prefer living in an economically egalitarian society. Of course, this does not, itself, tell us whether implementing an egalitarian economic policy in order to help those people would be justified. (If nothing else, perhaps it could be part of a case which also had other justifications). The point here has just been to point out that, if we take promoting the well-being of citizens as a proper role of government, there are non-paternalistic ways of taking the arguments of this chapter to support egalitarian economic policies.

But setting all that aside, even if the arguments of this chapter do not provide any kind of justification for implementing egalitarian economic policies, they nonetheless have interesting implications for egalitarian theory and practice. Here's one. Achieving a stable egalitarian society is not just a matter of working out which laws a just society would pass. It is also a matter of articulating attractive egalitarian norms and promoting those among the members of society. An egalitarian ethos is necessary if egalitarian laws are going to be passed and obeyed, and if people are going to treat one another as equals within the latitude granted by laws. And I think the arguments of the earlier sections can aid in developing and promulgating such an ethos.

In popular political discourse, those concerned about economic inequality are sometimes charged with promoting a "politics of envy"; the claim is that they cater to the unsavory jealousy of some for what the successful have. (For instance, Mitt Romney said as much during the (2012) presidential election Luhby (2012)). Egalitarian philosophers such as Dworkin (1980, p. 285) have sometimes played into this charge by suggesting that the criteria for whether an economic distribution is just is whether it is "envy-free", in the sense of being such that no one would prefer having someone else's bundle of resources rather than their own. Elizabeth Anderson has criticized this view, arguing both that it is "embarrassing for egalitarians" (Anderson 1999, p. 287) and that it is implausible and unattractive:

If much recent academic work defending equality had been secretly penned by conservatives, could the results be any more embarrassing for egalitarians? Consider how much of this work leaves itself open to classic and devastating conservative criticisms. Ronald Dworkin defines equality as an "envy-free" distribution of resources. This feeds the suspicion that the motive behind egalitarian policies is mere envy....

Envy's thought is "I want what you have." It is hard to see how such wants can generate obligations on the part of the envied. To even offer one's own envy as a reason to the envied to satisfy one's desire is profoundly disrespectful (Anderson 1999, pp. 287, 307). ${ }^{17}$

Anderson thinks that, instead of equality of resources of the sort defended by Dworkin, we should care fundamentally about social equality (or, as she calls it, "democratic equality"). And, like Jonathan Wolff, she thinks social equality with a fairly large degree of economic inequality; for instance, she rejects Rawls' difference principle as too "demanding" (Anderson 1999, p. 326).

But if my view is right, the standard-bearers of economic inequality, those living lives of vast wealth, are generally not in an enviable position. The reasonable attitude towards them, whatever it is, will be something complicated; their situation is at least partly their own doing, and has hurt the rest of society, but has also hurt them. If it became widely accepted that there were good arguments for this view, it would have several implications. One is that there would be an answer to the criticism that concern for economic inequality is driven by envy-namely, that, at least in the case of the vastly wealthy, people are not likely to be envious of them anyway, since their position is widely recognized

17 I think Anderson is actually unfair to Dworkin here. The envy test is a test; it is supposed to tell us that, when a distribution is envy free, it is just. That doesn't mean that the fact that the distribution is envy free is why it is just, or is the reason for aiming at that distribution, and, in fact, I think Dworkin would reject those claims. But this doesn't matter too much, since, if I am right, the envy test fails anyway 
to be unenviable. We could thus respond to the anti-egalitarian argument without compromising our commitment to economic equality. A second is that egalitarian philosophers would not be tempted to make embarrassing pronouncements about eliminating envy, and could instead focus on developing and articulating more plausible and attractive justifications for their views. A third is that, to the extent that ordinary people actually are envious of those living lives of vast wealth, this might help convince them that living such lives is not something desirable. We would successfully combat envy after all, but by showing it to be misguided rather than by catering to it.

A fourth is that this view might help motivate those living lives of vast wealth to support egalitarianism, rather than impeding it in the pursuit of perceived self-interest. We all know that the very wealthy commonly use their wealth and status in order to protect their ability to lead lives of vast wealth. They use donations to curry favor with politicians, obtain favorable results from regulators using the prospects of cushy corporate jobs (the phenomenon known as "regulatory capture"), fund research that supports their agendas, and so on (see (Oreskes and Conway 2010); (Stiglitz 2012)). In doing these things, they harm the worst-off, exacerbate economic inequality, and corrode the integrity of our democratic institutions. Certain legal steps (such as campaign finance reform) might be able to alleviate some of these problems, but, in a tragic irony, it's difficult to get such measures implemented as long as the problem they're meant to address exists.

However, if a consensus formed that living a life of vast wealth wasn't really desirable anyway, the wealthy might naturally be less inclined to impede the proper functioning of government so as to promote their ability to live such lives. Roughly this point is made by Robert H. Frank when he writes:

Although big-money donors are a diverse group, many of them want lower tax rates for themselves and less stringent regulations for their businesses—and they've been brilliantly effective in getting them. Their success has increased their incomes still further, allowing them to make even larger contributions and to demand even bigger favors. This vicious circle was strengthened considerably by the Supreme Court's decision in the Citizen's United Case. And so, each year, the possibility of new laws to curb money's influence appears to recede...

Reformers castigate wealthy donors for supporting self-serving policies. But instead, the reformers could call attention to the evidence that the donors themselves would fare better, in purely practical terms, without the tax cuts and deregulation they've been promoting. You don't have to be a cynical economist to believe that the second strategy has brighter prospects (Frank 2012c).

Capitalism has proven extremely effective at harnessing the human inclination to look out for oneself. In doing so it has produced tremendous material prosperity, but also, very often, great economic inequality. However, if the arguments in earlier sections were to become widely endorsed, enlightened self-interest might be harnessed to promote economic equality, rather than hinder it. ${ }^{18}$ Disseminating arguments like this might then be a useful component in the egalitarian toolbox. I am substantially less sanguine than Frank appears to be about the prospects of converting the wealthy en masse. (I'd be happy if we convinced anyone at all). But in an era of increasing inequality, I think we should take what we can get.

\section{Conclusions}

As mentioned earlier, I do not regard the argument I have presented here as decisive in their present forms. Many of the relevant issues deserve further study. However, I hope to have shown that there is a good case to be made for the conclusions that (1) vast wealth tends to be bad for people, or at least not nearly as good for them as one might think, (2) egalitarian economic policies would probably

18 This way of putting the point was suggested by one of the referees for Religions. 
tend to benefit vastly wealthy people on balance, and (3) these facts have interesting implications for egalitarian theory and practice.

Acknowledgments: I am grateful to many people for feedback on and discussions of various versions of this paper, including Paul Weithman, David Solomon, Marilie Coetsee, Sylwia Wilczewska, David Jost, Nathan Hershberger, the editors of this volume, participants at the "Growing Apart: the Implications of Economic Inequality" conference at Boston University, the taxi driver who took me to that conference, and two anonymous referees for Religions. I am also grateful to my cats, Artemis and Apollo, who did not provide feedback on the paper, but did inspire an example in Section 2, as well as providing emotional support and encouragement during the paper's writing.

Conflicts of Interest: The author declares no conflict of interest.

\section{References}

Anderson, Elizabeth. 1999. What is the Point of Equality? Ethics 109: 287-337. [CrossRef]

Buffett, Warren. 2010. My Philanthropic Pledge. Available online: Givingpledge.org (accessed on 2 September 2016).

Clark, Andrew E., Conchita D'Ambrosio, and Simone Ghislandi. 2013. Poverty and Well-being: Panel Evidence from Germany. Society for the Study of Economic Inequality Working Papers Series. Available online: http:/ / www.ecineq.org/milano/WP/ECINEQ2013-291.pdf (accessed on 2 September 2016).

Coffey, Brendan. 2015. Pledge Aside, Dead Billionaires Don't Have to Give Away Half Their Fortune. Bloomberg. Available online: http:/ / www.bloomberg.com/news/articles/2015-06-04/as-billionaires-bask-in-glowof-pledge-giving-half-is-optional (accessed on 2 September 2016).

Cohen, Gerald Allan. 2009. Why Not Socialism? Princeton: Princeton University Press.

Collier, Charles. 2012. Wealth in Families, 3rd ed. Cambridge: President and Fellows of Harvard College.

Conly, Sarah. 2012. Against Autonomy: Justifying Coercive Paternalism. Cambridge: Cambridge University Press.

Christian Coons, and Michael Weber, eds. 2013. Paternalism: Theory and Practice. Cambridge: Cambridge University Press.

Creswell, Julie. 2011. Even Funds That Lagged Paid Richly. New York Times. Available online: http://www. nytimes.com/2011/04/01/business/01hedge.html (accessed on 26 August 2016).

Crisp, Roger. 2006. Reasons and the Good. Oxford: Oxford University Press.

Crisp, Roger. 2013. Well-Being. Stanford Encyclopedia of Philosophy. Available online: http://plato.stanford.edu/ entries/well-being/ (accessed on 2 September 2016).

Dancy, Jonathan. 2004. Ethics without Principles. Oxford: Oxford University Press.

DeNavas-Walt, Carmen, and Bernadette D. Proctor. 2015. Income and Poverty in the United States: 2014. In United States Census Bureau. Available online: http:/ /www.census.gov/library/publications/2015/demo/p60-252. html (accessed on 26 August 2016).

Dworkin, Ronald. 1980. What is Equality? Part 2: Equality of Resources. Philosophy \& Public Affairs 10: $283-345$.

Ekstrom, Laura. 2013. A Christian Theodicy. In The Blackwell Companion to the Problem of Evil. Edited by Justin P. McBrayer and Daniel Howard-Snyder. Malden: Wiley-Blackwell.

Feeney, Brooke C., and Nancy L. Collins. 2015. A New Look at Social Support: A Theoretical Perspective on Thriving Through Relationships. Personality and Social Psychology Review 19: 113-47. [CrossRef] [PubMed]

Florida, Richard, and Charlotta Mellander. 2015. Segregated City: The Geography of Economic Segregation in America's Metros. Martin Prosperity Institute. Available online: http://martinprosperity.org/content/ segregated-city/ (accessed on 26 April 2017).

Frank, Robert. 2012a. Rich Kids Worry Money Will Strain Family Ties. CNBC. Available online: http:/ /www.cnbc. com/id/47726433 (accessed on 2 September 2016).

Frank, Robert. 2012b. Millionaire Parents Say Their Kids Are Unfit to Inherit. CNBC. Available online: http: / / www.cnbc.com/id/47859258 (accessed on 2 September 2016).

Frank, Robert H. 2012c. When Low Taxes Don't Help the Rich. The New York Times. Available online: http:/ / www. nytimes.com/2012/10/28/business/how-rich-political-donors-are-hurting-themselves.html (accessed on 2 September 2016).

Frank, Robert. 2013. Wealthy Don't Want to Spoil Kids, but Can't Help It. CNBC. Available online: http: / / www.cnbc.com/id/100367067 (accessed on 2 September 2016).

Frank, Robert. 2015. Top 20 Billionaires Worth as Much as Half of America. CNBC. Available online: http: //www.cnbc.com/2015/12/04/top-20-billionaires-worth-as-much-as-half-of-america.html (accessed on 26 August 2016). 
Frank, Robert H. 2011. The Darwin Economy: Liberty, Competition, and the Common Good. Princeton: Princeton University Press.

Frankfurt, Harry. 2015. On Inequality. Princeton: Princeton University Press.

Independent Sector. 2001. Giving \& Volunteering in the United States: Findings from a National Survey. Available online: http:/ / www.cpanda.org/pdfs/gv/GV01Report.pdf (accessed on 2 September 2016).

Greenstone, Michael, and Adam Looney. 2012. The Uncomfortable Truth about American Wages. New York Times. Available online: http:/ / economix.blogs.nytimes.com/2012/10/22/the-uncomfortable-truth-aboutamerican-wages / (accessed on 26 August 2016).

Griffin, James. 1986. Well-Being: Its Meaning, Measurement, and Moral Importance. Oxford: Clarendon Press.

Heathwood, Chris. 2006. Desire Satisfactionism and Hedonism. Philosophical Studies 128: 539-63. [CrossRef]

Heathwood, Chris. 2014. Subjective Theories of Well-being. In The Cambridge Companion to Utilitarianism. Edited by Ben Eggleston and Dale E. Miller. Cambridge: Cambridge University Press.

Kagan, Shelly. 2009. Well-Being as Enjoying the Good. Philosophical Perspectives 23: 253-72. [CrossRef]

Kahneman, Daniel, and Angus Deaton. 2010. High Income Improves Evaluation of Life but not Emotional Well-Being. Proceedings of the National Academy of Sciences of the United States of America 103: 16489-93. [CrossRef] [PubMed]

Kahneman, Daniel, Jack L. Knetsch, and Richard H. Thaler. 1991. The Endowment Effect, Loss Aversion, and Status Quo Bias. The Journal of Economic Perspectives 5: 193-206. [CrossRef]

Khader, Serene J. 2011. Adaptive Preferences and Women's Empowerment. Oxford: Oxford University Press.

Kraus, Michael W., Paul K. Piff, Rodolfo Mendoza-Denton, Michelle L. Rheinschmidt, and Dacher Keltner. 2012. Social Class, Solipsism, and Contextualism: How the Rich are Different from the Poor. Psychological Review 119: 546-72.

Lamont, Julian, and Christi Favor. 2013. Distributive Justice. Stanford Encyclopedia of Philosophy. Available online: https://plato.stanford.edu/entries/justice-distributive/ (accessed on 26 April 2017).

Lauinger, William. 2013. The Missing Desires Objection to Hybrid Theories of Well-Being. The Southern Journal of Philosophy 51: 270-95. [CrossRef]

Lombardo, Franco. 2012. The Great White Elephant: Why Rich Kids Hate Their Parents! White Rock: Roper House Publishing.

Luhby, Tami. 2012. Romney: Income Inequality Is Just ‘Envy'. CNN.com. Available online: http://money.cnn. com/2012/01/12/news/economy/romney_envy/ (accessed on 5 September 2016).

Matthews, Dylan. 2012. Wages Aren't Stagnating, They're Plummeting. Washington Post. Available online: http://www. washingtonpost.com/blogs/wonkblog/wp/2012/07/31/wages-arent-stagnating-theyre-plummeting/ (accessed on 14 December 2013).

Nozick, Robert. 1974. Anarchy, State, and Utopia. New York: Basic Books.

Oreskes, Naomi, and Erik M. Conway. 2010. Merchants of Doubt: How a Handful of Scientists Obscured the Truth on Issues from Tobacco Smoke to Global Warming. New York: Bloomsbury Press.

Parfit, Derek. 1984. Reasons and Persons. Oxford: Oxford University Press.

Parfit, Derek, and Samuel Scheffler. 2011. On What Matters, Volume I. Oxford: Oxford University Press.

Piff, Paul K. 2013. Wealth and the Inflated Self: Class, Entitlement, and Narcissism. Personality and Social Psychology Bulletin 40: 34-43. [CrossRef] [PubMed]

Piff, Paul K., Michael W. Kraus, Stèphane Cotè, Bonnie Hayden Cheng, and Dacher Keltner. 2010. Having Less, Giving More: The Influence of Social Class on Prosocial Behavior. Journal of Personality and Social Psychology 99: 771-84. [CrossRef] [PubMed]

Piff, Paul K., Daniel M. Stancato, Andres G. Martinez, Michael W. Kraus, and Dacher Keltner. 2012. Class, Chaos, and the Construction of Community. Journal of Personality and Social Psychology 103: 949-62. [CrossRef] [PubMed]

Piff, Paul K., Daniel M. Stancato, Stèphane Cotè, Rodolfo Mendoza-Denton, and Dacher Keltner. 2013. Higher Social Class Predicts Increased Unethical Behavior. Proceedings of the National Academy of Sciences of the United States of America 109: 4086-91. [CrossRef] [PubMed]

Rawls, John. 1999. A Theory of Justice: Revised Edition. Cambridge: Harvard University Press.

Railton, Peter. 1986. Facts and Values. Philosophical Topics 14: 5-31. [CrossRef]

Rooney, Ben. 2013. Stocks: 2013 Is One for the Books. CNN. Available online: http://buzz.money.cnn.com/2013/ 12/31/stocks-record-bull-market/ (accessed on 26 August 2016). 
Scheffler, Samuel. 2015. The Practice of Equality. In Social Equality: On What it Means to Be Equals. Edited by Carina Fourie, Fabian Schuppert and Ivo Wallimann-Helmer. Oxford: Oxford University Press.

Shiller, Robert. 2012. High Taxes Needn't Discourage Philanthropy. New York Times. Available online: http:/ / www. nytimes.com/2012/07/29/business/if-raising-top-tax-rates-encourage-charitable-giving.html?_r=0 (accessed on 2 September 2016).

Stiglitz, Joseph. 2012. The Price of Inequality: How Today's Divided Society Endangers Our Future. New York: W. W. Norton.

Stern, Ken. 2013. Why the Rich Don't Give to Charity. The Atlantic. Available online: http://www.theatlantic. com/magazine/archive/2013/04/why-the-rich-dont-give/309254/ (accessed on 2 September 2016).

Stroud, Sarah. 2014. Weakness of Will. Stanford Encyclopedia of Philosophy. Available online: https://plato.stanford. edu/entries/weakness-will/ (accessed on 26 April 2017).

Vardi, Nathan. 2014. The Twenty-Five Highest-Earning Hedge Fund Managers and Traders. Forbes. Available online: http:/ / www.forbes.com/sites/nathanvardi/2014/02/26/the-highest-earning-hedge-fund-managersand-traders/\#212421af1984 (accessed on 26 August 2016).

Social Security Administration. 2013. Wage Statistics for 2013. Available online: https:/ /www.ssa.gov/cgi-bin/ netcomp.cgi?year=2013 (accessed on 26 August 2016).

Ward, Kate. 2016. Wealth, Poverty and Economic Inequality: A Christian Virtue Response. Available online: https: / / search.proquest.com/docview/1797412295?accountid=100 (accessed on 24 April 2017).

Wilkinson, Richard, and Kate Pickett. 2010. The Spirit Level: Why Greater Equality Makes Societies Stronger. New York: Bloomsbury Press.

Willis, Thayer Chatham. 2012. Beyond Gold: True Wealth for Inheritors. Portland: New Concord Press.

Willis, Thayer. 2013. Why Family Wealth Is a Curse. Forbes. Available online: http://www.forbes.com/sites / deborahljacobs/2013/03/01/why-family-wealth-is-a-curse/\#439d9a537fc1 (accessed on 2 September 2016).

Wolff, Jonathan. 2015. Social Equality and Social Inequality. In Social Equality: On What it Means to Be Equals. Edited by Carina Fourie, Fabian Schuppert and Ivo Wallimann-Helmer. Oxford: Oxford University Press.

(C) 2017 by the author. Licensee MDPI, Basel, Switzerland. This article is an open access article distributed under the terms and conditions of the Creative Commons Attribution (CC BY) license (http:/ / creativecommons.org/licenses/by/4.0/). 